\title{
Effects of ZnO nanoparticles on microbial biomass and enzyme activity in soils containing cellulose and lignin
}

\author{
Hao Jiang ${ }^{l}$, Hui Wang ${ }^{1, *}$, Baoshan Yang ${ }^{1}$, Xinlei Cao ${ }^{l}$, and Xingyue Liu ${ }^{l}$ \\ ${ }^{1}$ School of Water Conservancy and Environment, University of Jinan, 250022 Jinan, China
}

\begin{abstract}
In order to investigate the effect of $\mathrm{ZnO}$ nanoparticles (ZnONPs) on soil ecosystem in soil with added cellulose and lignin, five treatments were set up: cellulose, cellulose + ZnONPs, lignin, lignin + ZnONPs, and no addition. The soil respiration, microbial biomass, and the activities of soil enzymes were explored during a 56-day incubation time after the addition of ZnONPs. The results showed that when cellulose and lignin were added to the soil, the $\mathrm{CO}_{2}$ efflux increased by $90.9 \%$ and $18.2 \%$, respectively, compared with the control soil. The microbial biomass carbon and the activity of peroxidase, polyphenol oxidase, $\beta$-glucosidase and cellulase were increased. Compared with the treatment with the addition of cellulose and lignin only, the exposure of ZnONPs increased the $\mathrm{CO}_{2}$ efflux, microbial biomass carbon, $\beta$ glucosidase and cellulase activities, but decreased the peroxidase and polyphenol oxidase activities. We concluded that the addition of cellulose and lignin to farmland soil increased respiration, microbial biomass and soil enzyme activity, but the degradation degree of cellulose was higher than lignin. The ZnONPs promote soil respiration, microbial biomass, and hydrolase activity throughout the culture period, but inhibited the activity of redox enzymes.
\end{abstract}

\section{Introduction}

As nanoparticles (NPs) show many outstanding properties in optics, thermal, electrical, magnetic, mechanical, and chemical aspects, they have been widely used in various fields of production and life [1-2]. Among them, zinc oxide nanoparticles (ZnONPs) is one of the most common engineering NPs. According to statistics, by 2010, global production of ZnONPs has exceeded 30000 metric tons per year, which will lead to release of ZnONPs into the environment, resulting in their exposure to soil ecosystem [1, 3]. As emerging contaminants, ZnONPs has become an international research hotspot in terms of environmental safety and ecotoxicology.

Cellulose and lignin were the first and second richest components in plant tissues, accounting for $20 \%$ to $60 \%$ of crop residues, so their decomposition rate largely determines the amount of soil organic matter, and an important role in soil organic carbon of fixation and cycling [4-6]. The conversion of cellulose and lignin in the soil was a complex process, and was done by soil microorganisms [4]. However, the large accumulation of ZnONPs in farmland soil may affect soil respiration and microbial activity. Soil respiration was the second largest carbon flux between the atmosphere and terrestrial ecosystems and an important component of the global carbon cycle [7]. Rashid et al. [8] showed that the cultivable heterotrophic bacteria and soil respiration were significantly reduced by ZnONPs. Ge et al. [9] also found that soil respiration were significantly inhibited when exposed to ZnONPs concentrations of $0.05,0.01$, and $0.5 \mathrm{mg} / \mathrm{g}$. Endoglucanases, cellobiohydrolases, $\beta$ glucosidases, laccases and peroxidases were important enzymes involved in the degradation of cellulose and lignin, as well as important components of the carbon cycle of the ecosystem [4]. Du et al. [10] found that most hydrolases and oxidases were inhibited by ZnONPs, such as: $\beta$-glucosidase, acid phosphatase, polyphenol oxidase and peroxidase. You et al. [11] also found that similar results were obtained for the effects of $\mathrm{ZnO}, \mathrm{TiO}_{2}$, $\mathrm{CeO}_{2}$ and $\mathrm{Fe}_{3} \mathrm{O}_{4} \mathrm{NPs}$ on soil enzyme activities (invertase, urease, catalase, and phosphatase) and bacterial community in saline-alkali and black soil. However, the effects of ZnONPs on soil heterotrophic respiration, microbial biomass and enzyme activity under the addition of different exogenous organic matter have not been studied. Therefore, the effects of ZnONPs on soil heterotrophic respiration, microbial biomass, and enzyme activity under the conditions of adding cellulose and lignin were investigated, and the effect of $\mathrm{ZnONPs}$ on difficult and easily degradable organic matter in soil carbon cycling was investigated. It is of great significance to $\mathrm{ZnONPs}$ environmental risk assessment.

In this study, the effects of ZnONPs on soil heterotrophic respiration, microbial biomass, and enzyme activity were studied in a laboratory experiment by exposing the same concentrations of ZnONPs to soil containing cellulose and lignin.

\section{Materials and methods}

*Corresponding author: hwang118@126.com 


\subsection{Experiment materials}

The soil was collected from the farmland soil of Jinan City, Shandong Province $\left(117^{\circ} 23^{\prime} 31.11^{\prime \prime} \mathrm{E}\right.$, $36^{\circ} 40^{\prime} 5.23^{\prime \prime} \mathrm{N}$ ) in March 2018, and the sampling depth was $0 \sim 20 \mathrm{~cm}$. After sampling the soil, quickly bring them back to the laboratory, remove the plant residues, soil animal remains and stone, etc., and pass through a 2 $\mathrm{mm}$ sieve. The basic physicochemical properties of the tested soil are shown in Table 1.

Table 1. Basic physicochemical properties of test soil.

\begin{tabular}{|c|c|c|c|c|c|}
\hline $\mathrm{pH}$ & $\begin{array}{c}\text { Moisture } \\
\text { content } \\
(\%)\end{array}$ & $\begin{array}{c}\text { Organic } \\
\text { matter } \\
(\%)\end{array}$ & $\begin{array}{c}\mathrm{NO}_{3}{ }^{-}-\mathrm{N} \\
(\mathrm{mg} / \mathrm{kg})\end{array}$ & $\begin{array}{c}\mathrm{NH}_{4}{ }^{+}-\mathrm{N} \\
(\mathrm{mg} / \mathrm{kg})\end{array}$ & $\begin{array}{c}\mathrm{TN} \\
(\mathrm{g} / \mathrm{kg})\end{array}$ \\
\hline 7.35 & 10.13 & 1.66 & 6.18 & 8.03 & 0.83 \\
\hline
\end{tabular}

ZnONPs powder, purchased from Beijing Boyu Gaoke New Material Technology Co., Ltd., is light yellow with an average particle size of about $14.6 \mathrm{~nm}$, $\mathrm{ZnO}$ purity of $99.9 \%$, and specific surface area of 51.5 $\mathrm{m}^{2} / \mathrm{g}$.

Cellulose powder, purchased from Shanghai Aladdin Biochemical Technology Co., Ltd., white, with particle size of $90 \mu \mathrm{m}, \mathrm{pH}$ is 6.2 , and a carbon content of $44 \%$.

Lignin powder, purchased from Shanghai McLean Biochemical Technology Co., Ltd., black, particle size is $90 \mu \mathrm{m}, \mathrm{pH}$ is $3.0-4.0$, and carbon content is $60 \%$.

\subsection{Experimental design}

Pre-cultivate the test soil for one week $\left(25 \pm 3^{\circ} \mathrm{C}\right.$, dark conditions) to stabilize the soil microbial activity. Adjust the soil water content to $50 \%$ of the maximum water holding capacity during the cultivation [12]. The experiment set cellulose (CS), cellulose + ZnONPs (CZ), lignin (LS), lignin + ZnONPs (LZ), with no added soil as control (CK), a total of 5 treatments, each treatment repeated 3 times. The carbon content of addition of cellulose and lignin was equal to the carbon content of wheat straw (3450 kg/ha). ZnONPs concentration was $100 \mathrm{mg} / \mathrm{kg}$ [9].

$50 \mathrm{~g}$ soil (equivalent dry weight) was placed in $2.5 \mathrm{~L}$ jars which contained a $50 \mathrm{ml}$ beakers filled with $20 \mathrm{ml}$ $\mathrm{NaOH}(0.1 \mathrm{M})$. The corresponding ZnONPs, cellulose, and lignin were mixed evenly into the soil. The soil water content was adjusted to $50 \%$ of maximal water holding capacity. Jars were sealed tightly with butyl rubber stoppers and incubation at $25 \pm 3^{\circ} \mathrm{C}$ in darkness. A $20 \mathrm{~g}$ soil samples were periodically collected from each jar at 28 , and 56 days and stored at $4{ }^{\circ} \mathrm{C}$ to determine the soil microbial biomass and enzyme activities.

\subsection{Experimental method}

Soil respiration was measured using the $\mathrm{CO}_{2}$ absorption method [8]. Remove the beakers on days 2, 4, 7, 14, 21, 28,42 , and 56, respectively. Determine the $\mathrm{CO}_{2}$ release by $0.05 \mathrm{~mol} / \mathrm{L}$ HCL back titration and calculate the $\mathrm{CO}_{2}$ release rate.
Soil microbial biomass carbon (MBC) was measured by chloroform fumigation-potassium sulfate extraction method [8].

Peroxidase (POD) was determined by pyrogallol colorimetry [13]; polyphenol oxidase (PPO) was determined by pyrogallol colorimetry [13]; $\beta$ glucosidase (BG) was measured by nitrophenol colorimetry [13]; cellulose (CE) was measured by 3,5dinitrosalicylic acid colorimetry [13].

\subsection{Data analysis}

The test data were processed using Excel 2013 software, was analyzed using Origin 2018 software, and was statistically analyzed using SPSS 17.0 software.

\section{Results and discussion}

\subsection{Effect of ZnONPs on soil respiration}

The changes of $\mathrm{CO}_{2}$ release rate under the five treatments were shown in Table 2. After 14 days of culture, the $\mathrm{CO}_{2}$ release rate of cellulose treatment was significantly higher than that of the control group $(P<$ 0.05). The $\mathrm{CO}_{2}$ release rate of lignin treatment was significantly higher than that of the control group during the whole culture process $(P<0.05)$. After 56 days of culture, the $\mathrm{CO}_{2}$ release rate of cellulose treatment was higher than that of lignin treatment. It can be seen that the addition of cellulose and lignin both improved soil respiration, but the degradation of cellulose was higher than that of lignin. Research reports indicate that cellulose was generally considered more unstable [4]. Cellulose is a macromolecular polysaccharide composed of glucose. Lignin is a biopolymer with a threedimensional network structure formed by the connection of three phenylpropane units through ether bonds and carbon-carbon bonds [4]. Due to their different chemical composition and structure, cellulose usually breaks down faster than lignin [4]. On the other hand, the $\mathrm{CO}_{2}$ release rate of ZnONPs treatment $(100 \mathrm{mg} / \mathrm{kg})$ was significantly increased on the 56th day in the cellulose and lignin treatments $(P<0.05)$, indicating that $100 \mathrm{mg} / \mathrm{kg}$ of ZnONPs can promote soil respiration effect. This may be because the microbial community includes some taxa with functional compensation in the original community [9].

Table 2. The change of $\mathrm{CO}_{2}$ release rate under cellulose, ligin, and $\mathrm{ZnONPs}$ treatments.

\begin{tabular}{|c|c|c|c|c|c|}
\hline \multirow{2}{*}{$\begin{array}{l}\text { Day } \\
\text { s }\end{array}$} & \multicolumn{5}{|c|}{ Treatments } \\
\hline & $\mathrm{CK}$ & $\mathrm{CS}$ & $\mathrm{CZ}$ & LS & $\mathrm{LZ}$ \\
\hline 2 & $\begin{array}{l}6.3 \pm 0.2 \\
\mathrm{a}\end{array}$ & $\begin{array}{l}6.7 \pm 0.1 \mathrm{a} \\
\mathrm{b}\end{array}$ & $\begin{array}{l}7.0 \pm 0.2 \\
\mathrm{~b}\end{array}$ & $8.7 \pm 0.1 \mathrm{c}$ & $9.1 \pm 0.3 \mathrm{c}$ \\
\hline 4 & $\begin{array}{l}5.9 \pm 0.2 \\
\mathrm{a}\end{array}$ & $6.2 \pm 0.2 \mathrm{a}$ & $\begin{array}{l}6.4 \pm 0.2 \\
\mathrm{a}\end{array}$ & $8.7 \pm 0.1 b$ & $8.7 \pm 0.1 b$ \\
\hline 7 & $\begin{array}{l}4.1 \pm 0.1 \\
\mathrm{a}\end{array}$ & $4.2 \pm 0.1 \mathrm{a}$ & $\begin{array}{l}4.3 \pm 0.2 \\
\mathrm{a}\end{array}$ & $5.1 \pm 0.0 \mathrm{~b}$ & $5.2 \pm 0.1 \mathrm{~b}$ \\
\hline 14 & $\begin{array}{l}2.4 \pm 0.1 \\
\mathrm{a}\end{array}$ & $2.8 \pm 0.1 b$ & $\begin{array}{l}2.7 \pm 0.1 \\
\mathrm{~b}\end{array}$ & $\begin{array}{l}2.6 \pm 0.1 \mathrm{a} \\
\mathrm{b}\end{array}$ & $\begin{array}{l}2.5 \pm 0.1 \mathrm{a} \\
\mathrm{b}\end{array}$ \\
\hline 21 & $1.8 \pm 0.1$ & $3.7 \pm 0.1 \mathrm{c}$ & $3.5 \pm 0.1$ & $3.0 \pm 0.1 \mathrm{~b}$ & $2.9 \pm 0.2 b$ \\
\hline
\end{tabular}




\begin{tabular}{|l|l|l|l|l|l|}
\hline & $\mathrm{a}$ & & $\mathrm{c}$ & & \\
\hline 28 & $\begin{array}{l}1.9 \pm 0.1 \\
\mathrm{a}\end{array}$ & $3.1 \pm 0.1 \mathrm{c}$ & $\begin{array}{l}3.7 \pm 0.0 \\
\mathrm{~d}\end{array}$ & $2.6 \pm 0.0 \mathrm{~b}$ & $2.7 \pm 0.0 \mathrm{~b}$ \\
\hline 42 & $\begin{array}{l}1.3 \pm 0.0 \\
\mathrm{a}\end{array}$ & $2.5 \pm 0.1 \mathrm{c}$ & $\begin{array}{l}2.8 \pm 0.1 \\
\mathrm{c}\end{array}$ & $1.9 \pm 0.1 \mathrm{~b}$ & $2.0 \pm 0.1 \mathrm{~b}$ \\
\hline 56 & $\begin{array}{l}1.1 \pm 0.1 \\
\mathrm{a}\end{array}$ & $2.1 \pm 0.1 \mathrm{c}$ & $\begin{array}{l}2.4 \pm 0.0 \\
\mathrm{~d}\end{array}$ & $1.3 \pm 0.0 \mathrm{a}$ & $1.8 \pm 0.1 \mathrm{~b}$ \\
\hline
\end{tabular}

Lowercase letters $\mathrm{a}, \mathrm{b}$, and $\mathrm{c}$ indicate significant differences between treatments on the same number of days $(\mathrm{P}<0.05), \mathrm{n}=$ 3. Same as below.

\subsection{Effect of ZnONPs on microbial biomass}

In this experiment, $\mathrm{MBC}$ was used to represent soil microbial biomass. MBC was different effects under cellulose, lignin, and ZnONPs treatments (Fig. 1). Trends of MBC in cellulose and lignin treatments were similar. At 28 days, there was no significant different between the treatments $(P>0.05)$, and at 56 days, CS, $\mathrm{CZ}$, LS, and LZ were significantly higher than the control $(P<0.05)$, and the MBC content of ZnONPs treatment was the highest in the treatment of adding cellulose and lignin $(P>0.05)$. It can be seen that the addition of cellulose and lignin promoted soil microbial biomass, and exposure of $100 \mathrm{mg} / \mathrm{kg} \mathrm{ZnONPs}$ increased the increase in soil microbial biomass. Zinc is a mineral element, the so-called micronutrient element. $\mathrm{Zn}^{2+}$ can promote the growth of microorganisms and increase biomass [14]. This is similar to the findings of Ge et al. [9]. In addition, Rashid et al. [8, 15] found that high concentrations of ZnONPs $(1000 \mathrm{mg} / \mathrm{kg}$ ) and iron oxide nanomaterials $(2000 \mathrm{mg} / \mathrm{kg})$ reduced MBC. It can be seen that the change of MBC is related to the dose and type of nanomaterials.

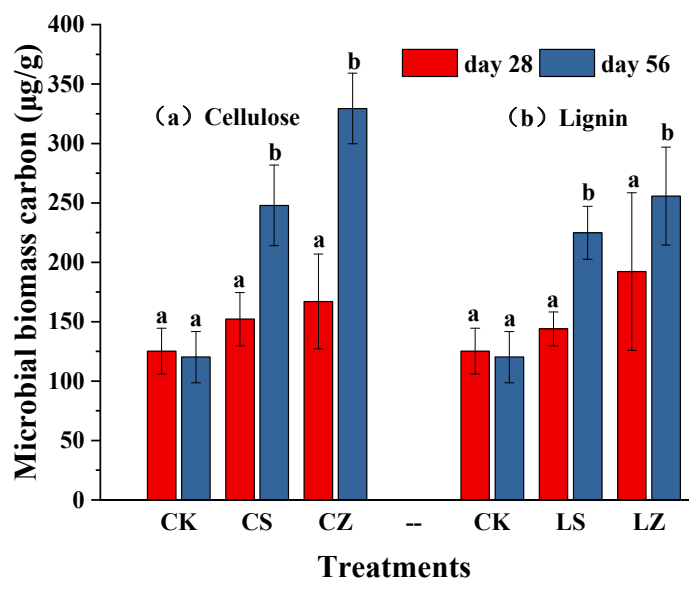

Fig. 1. The change of microbial biomass carbon under cellulose, lignin, and $\mathrm{ZnONPs}$ treatments.

\subsection{Effect of ZnONPs on oxidoreductase}

The change of soil oxidoreductase activity under five treatments was shown in Fig. 2. On the 28th day after adding lignin, the peroxidase activity of ZnONPs treatment was significantly lower than that of LS $(P<$ 0.05 ); the polyphenol oxidase activity was significantly reduced under exposure to ZnONPs $(P<0.05)$. It can be seen that ZnONPs have a certain inhibitory effect on soil oxidoreductase. Both peroxidase and polyphenol oxidase belong to the soil oxidoreductase system and occupy a very important position in the conversion of soil material and energy. It is involved in the synthesis of soil humus components and in the process of soil formation [13]. Studies have shown that under low concentrations of heavy metal pollution, dehydrogenase activity is only $56-80 \%$ of the control (zinc). After zinc is applied to the soil, the presence of heavy metal has a significant inhibitory effect on redox enzymes [16]. Heavy metals can react with sulfhydryl groups to form metallothioneins, thereby deactivating or inhibiting the enzyme [17]. Due to the smaller particle size of ZnONPs, it is easier to dissolve in the soil [18]. Interaction between nanomaterials and soil microbial cells generates oxidative stress, resulting in weakened microbial activity and even death, thereby reducing soil enzyme production and release [19].
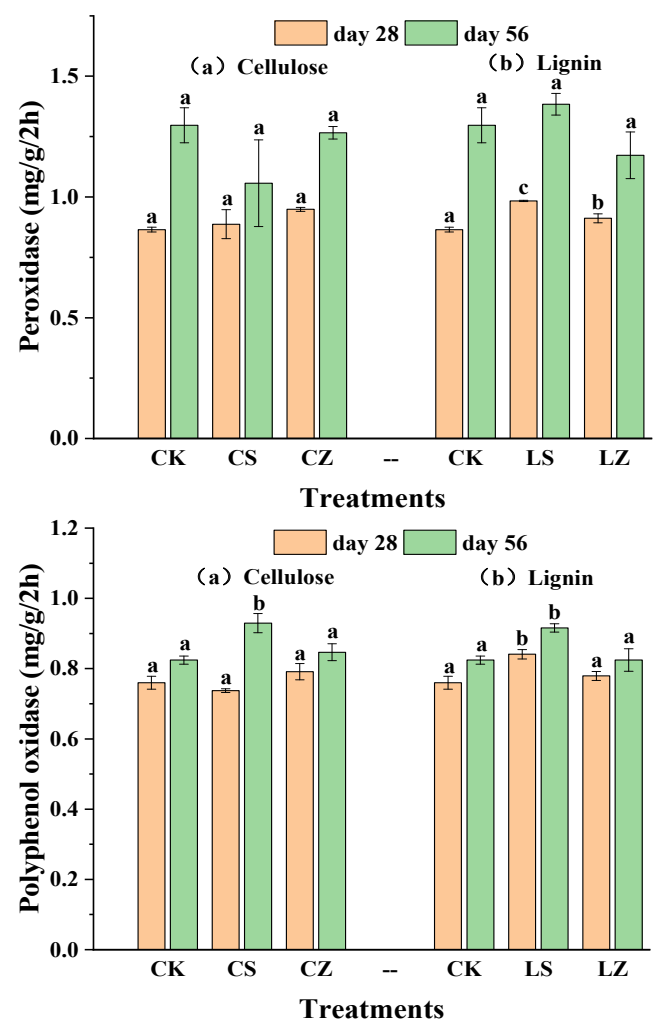

Fig. 2. The change of oxidoreductase activity under cellulose, lignin, and $\mathrm{ZnONPs}$ treatments.

\subsection{Effect of ZnONPs on soil hydrolase}

The changes of soil hydrolase activity under five treatments are shown in Fig. 3. For $\beta$-glucosidase, the exposure of $\mathrm{ZnONPs}$ significantly increased the activity of $\beta$-glucosidase in the cellulose-added treatment $(P<$ 0.05 ), but in the lignin-added treatment, there was no significant difference between LZ and LS $(P>0.05)$. As for cellulase, there was no significant difference between the treatments on the 28th day after adding cellulose and lignin $(P>0.05)$. On the 56th day after culture, the cellulase in cellulose and lignin treatment was significantly higher than control treatment $(P<0.05)$. It can be seen that the addition of cellulose and lignin 
promoted the activity of $\beta$-glucosidase and cellulase, and that $100 \mathrm{mg} / \mathrm{kg}$ of $\mathrm{ZnONPs}$ had certain promotion effects on activity of $\beta$-glucosidase and cellulase. Trace elements in nutrients are indispensable as cofactors of the enzyme system and constituents of metalloenzymes [20]. Studies have shown that under low copper concentration treatment, organic materials can sequester copper, and water-soluble and exchangeable copper ions with high bioavailability are just in the activation range, thereby increasing the enzyme activity [21]. This may be an important reason for the increase of $\beta$-glucosidase and cellulase under the treatment of $100 \mathrm{mg} / \mathrm{kg} \mathrm{ZnONPs}$.
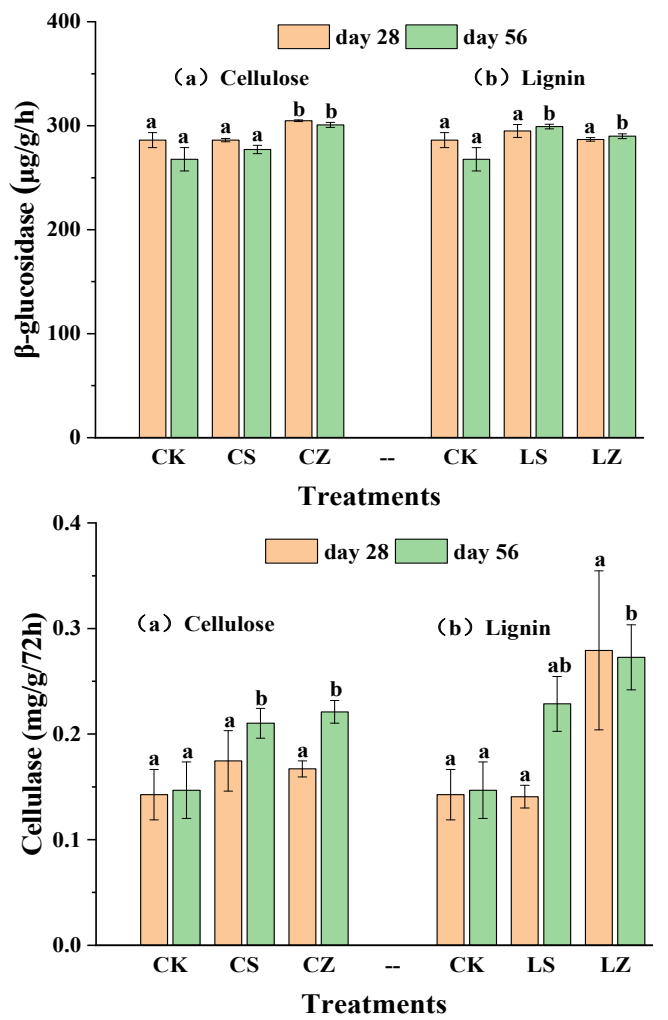

Fig. 3. The change of hydrolase activity under cellulose, lignin, and $\mathrm{ZnONPs}$ treatments.

\subsection{Correlation analysis of soil respiration, soil microbial biomass and soil enzyme activity}

In order to analyze the relationship between ZnONPs on soil respiration, soil biomass and soil enzymes in soil with added cellulose and lignin, the correlation between soil respiration and soil microbial biomass and soil enzymes on day 56 was analyzed. It can be seen from Table 3 that soil respiration have a positive correlation with soil microbial biomass, polyphenol oxidase, $\beta$ glucosidase, and cellulase, and a negative correlation with peroxidase. During cellulose treatment, soil respiration was extremely significantly positively correlated with soil microbial biomass and cellulase $(P<$ $0.01)$, and significantly positively correlated with $\beta$ glucosidase $(P<0.05)$. In lignin treatment, soil respiration was significantly positively correlated with polyphenol oxidase and cellulase $(P<0.05)$. It can be seen that the soil microbial biomass and soil enzyme activity will affect soil respiration, and then affect soil carbon cycling.

Table 3. The correlation between soil respiration and microbial factors.

\begin{tabular}{|l|l|l|l|l|l|l|}
\hline $\begin{array}{l}\text { Cor } \\
\text { rela } \\
\text { tion } \\
(R)\end{array}$ & $\begin{array}{l}\text { Treatment } \\
\mathrm{s}\end{array}$ & $\begin{array}{l}\text { Micro } \\
\text { bial } \\
\text { bioma } \\
\text { ss }\end{array}$ & POD & PPO & BG & CE \\
\hline $\begin{array}{l}\mathrm{CO}_{2} \\
\text { rele }\end{array}$ & Cellulose & $\begin{array}{l}0.829 \\
* *\end{array}$ & -0.236 & $\begin{array}{l}0.45 \\
0\end{array}$ & $\begin{array}{l}0.65 \\
2 *\end{array}$ & $\begin{array}{l}0.767 \\
* *\end{array}$ \\
\cline { 2 - 7 } $\begin{array}{l}\text { ase } \\
\text { rate }\end{array}$ & Lignin & 0.405 & -0.328 & $\begin{array}{l}0.68 \\
5 *\end{array}$ & $\begin{array}{l}0.37 \\
1\end{array}$ & $\begin{array}{l}0.708 \\
*\end{array}$ \\
\hline
\end{tabular}

* indicate $P<0.05$; ** indicate $P<0.01$.

\section{Conclusions}

Conclusions from experimental research:

(a) The addition of cellulose and lignin promoted soil respiration, but the degradation of cellulose was higher than that of lignin, and soil respiration was enhanced under the exposure of $100 \mathrm{mg} / \mathrm{kg} \mathrm{ZnONPs}$.

(b) The addition of cellulose and lignin promoted soil microbial biomass, and the addition of $100 \mathrm{mg} / \mathrm{kg}$ ZnONPs increased the increase in soil microbial biomass.

(c) ZnONPs has a significant inhibitory effect on soil oxidoreductase and a certain promotion effect on soil hydrolase.

\section{Acknowledgement}

This research was supported by National Natural Science Foundation of China (41877424; 31870606), Natural Science Foundation of Shandong Province (ZR2018MD002; ZR2017MD022).

\section{References}

1. J.L. Cao, Y.Z. Feng, X.G. Lin, Acta Pedologica Sinica. 53, 1-11 (2016).

2. J. Xiao, J. Huang, C. Peng, C. Cao, C.N. Yan. Journal of Southeast University (Natural Science Edition). 49, 178-185 (2019).

3. V.L.R. Pullagurala, I.O. Adisa, S. Rawat, S. Kalagara, J.A.H. Viezcas, J.R. Peralta-Videa, J.L. Gardea-Torresdey, Plant Physiol. Bioch. 132, 120127 (2018).

4. X.B. Chen, Y.J. Hu, S.Z. Feng, Y.C. Rui, Z.H. Zhang, H.B. He, X.H. He, T.D. Ge, J.S. Wu, Y.R. Su, Sci Rep-UK. 8, 1633 (2018).

5. C. Koechli, A.N. Campbell, C. Pepe-Ranney, D.H. Buckley, Soil Bio. Biochem. 130, 150-158 (2019).

6. Y. Wang, H. Zheng, F. Chen, J. Zeng, Z.Y. Quyang, Appl. Soil Ecol. 138, 213-219 (2019).

7. B.W. Wang, S.J. Chi, S.Z. Tian, T.Y. Ning, H.F. Han, H.X. Zhao, Z.J. Li, Chinese Journal of Applied Ecology. 24, 1374-1380 (2013). 
8. M.I. Rashid, T. Shahzad, M. Shahid, I.M.I. Ismail, G.M. Shah, T. Almeelbi, J. Hazard. Mater. 324, 298-305 (2017).

9. Y. Ge, J.P. Schimel, P.A. Holden, Environ. Sci. Technol. 45, 1659-1664 (2011).

10. J.J. Du, Y.Y. Zhang, L. Liu, M.X. Qv, Y. Lv, Y.F. Yin, Y.F. Zhou, M.H. Cui, Y.F. Zhu, H.Z. Zhang, Chemosphere. 187, 368-375 (2017).

11. T.T. You, D.D. Liu, J. Chen, Z.Z.Yang, R.Z. Dou, X. Gao, L. Wang, J. Soils Sediments. 18, 211-221 (2017).

12. Q.S. Wang, X.C. Qi, T.L. Shen, C.L. Li, Acta Scientiae Circumstantiae. 37, 3149-3157 (2017).

13. S.Y. Guan, Soil enzymes and research methods. (1983).

14. H. Sturikova, O. Krystofova, D. Huska, V. Adam, J. Hazard. Mater. 349, 101-110 (2018).

15. M.I. Rashid, T. Shahzad, M. Shahid, M. Imran, J. Dhavamani, I.M.I. Ismail, J.M. Basahi, T. Almeelbi, Sci Rep-UK. 7, 41965 (2017).
16. W.J. Zhang, Northwest A\&F University. (2011).

17. Q.Q. Shi, D.L. Deng, C. Yan, S.Y. Pu, Asian Journal of Ecotoxicology. 13, 47-56 (2018).

18. H.T. Zhao, C.W. Hu, Biotechworld. 96, 263-265 (2016).

19. Y.Q. Sun, C.C. Shen, Y. Ge, Asian Journal of Ecotoxicology. 11, 2-13 (2016).

20. L. Chen, Contemporary Animal Husbandry. 4, 22 (1991).

21. X.L. Xing, J. Gu, H. Gao, Q.J. Qin, W.J. Zhang, H.L. Li, S.N. Chen, J. Liu, H.B. Zhang L. Chen, L. Shao, Journal of Agro-Environment Science. 30, 375-382 (2011). 